УДК 330.3:336.6:330.43

J. Atanasijevic, B. Najman

\title{
FINANCIAL INTEGRATION AND MACROECONOMIC SUSTAINABILITY: A SECTOR APPROACH TO ACCESS THE FINANCE AND THE PRE-CRISIS GROWTH MODEL
}

\begin{abstract}
We analyze the determinants of financial constraints in 18 transition countries in Europe on a dataset from the enterprise level survey provided by EBRD in four turns from 2002 to 2008. All these countries had in common the fact that prior to the crisis they had based their growth model on financial integration (EBRD, 2009). Examining in depth the financing obstacle to business may bring some genuine answers on financial development and its effects on the growth of the real sector. The main result of the empirical estimation using the probit methodology is that a higher probability of financial constraint exists for a manufacturing enterprises in contrast to other industries. Besides an increased probability of facing access to finance as a very severe business obstacle, the estimation also reveals that manufacturing firms have more need for loans. In addition, the firms not using bank loans are more prone to state high interest rates and non-favorable non-price loan terms as reasons for not using external financing. This finding inspired us to formulate a more general hypothesis on the role of the financial sector in the macroeconomic effects of the applied development model in transition economies during the period before the crisis. Namely, two decades of uneven access to finance by manufacturing businesses (producing tradable goods) resulted in structural imbalances in the real sector that reflected in trade deficit, i.e. the underdeveloped tradable sector and the overdeveloped non-tradable.
\end{abstract}

Keywords: access to finance, manufacturing, transition, firms.

JEL classification: O14, L20, C01

\section{Introduction}

"The availability and access to finance can be a crucial influence on the economic entitlements that economic agents are practically able to secure. This applies all the way from large enterprises (in which hundreds of thousands of people may work) to tiny establishments that rely on microcredit," (Amartya Sen, 1999).

The rapid financial development was a powerful driver of growth and income convergence in all European transition economies until the sudden hit of the global crisis. During the financial expansion and credit boom, financial inflows were abundant and the pace of financial "leveraging" of companies and households was particularly strong. Amidst such developments, access to finance was naturally eased thanks to these financial inflows channeled through banks to households and companies. When banks are the major lenders to the economy, as is the case of all transition economies, the level and direction of real investment crucially depends on the decisions of banks, which projects are to be financed. The recall of the five main channels through which the development of the financial system influences economic growth, help to set the framework of underlying growth effects in the period of rapid financial development. As summarized by Levine (1997), economic growth is influenced by the development of the five different ways. First, financial development improves mobilizing and pooling of savings 
in an economy. Secondly, the better supply of information will lead to a better allocation of resources. Thirdly, there will be better incentives for monitoring of investments and implementation of corporate governance. Fourthly, it will become easier to trade, diversify and manage risks. Fifthly, transactions concerning goods and services will be facilitated. All these advantages of having a sound financial sector can contribute in two different ways to a higher per capita economic growth. Firstly, these advantages will lead to a higher capital stock (capital accumulation) and secondly they can speed up technological development. In this perception, a higher allocative efficiency leads to an increasing propensity to both save and invest, which stimulates capital accumulation and technological renewal. In the end, this will boost economic growth.

The comprehensive enterprise level survey, Business Environment and Enterprise Performance Survey (BEEPS), organized by European Bank for Reconstruction and Development and World Bank and conducted in all transition countries in 2008/2009 and previously in 2005 and 2002, offers a unique opportunity to explore the perception of enterprises regarding their business environment including the matter of the financing of their business. Summarizing the enterprise level answers from this survey to the question about their major business obstacle, the obtained result brings a somewhat puzzling result. Namely, amidst the intensive financial inflows in the form of foreign lending directly or through locally present foreign banks, that had brought the financial intermediation at the comparable level with developed market economies, 'the access to finance' represented the second largest obstacle for their business activities (after tax rates), as presented in Table 1.

Financial inclusion, or broad access to financial services, is usually defined as an absence of price or non-price barriers in the use of financial services. Of course, it does not mean that all households and firms should be able to borrow unlimited amounts at prime lending rates. Even if banks are competitive and employed the best financial technology, prices and interest rates charged and size of loans in the market economy will necessarily depend on the creditworthiness of the customer. Improving access then, means improving the degree to which financial services are available to all at a fair price. The specific feature of credit markets provide that market equilibrium may not occur even where demand equals supply.

In their well-known paper, Stiglitz and Weiss (1981) show that information problems can lead to credit rationing even in equilibrium. That is because
Table 1. Major business obstacle, summary for 18 European transition countries (Bosnia, Bulgaria, Croatia, Czech Republic, Estonia, FYROM, Hungary, Latvia, Lithuania, Moldova, Montenegro, Poland, Romania, Serbia, Slovakia, Slovenia, Ukraine)

\begin{tabular}{|l|c|c|c|c|}
\hline \multirow{2}{*}{$\begin{array}{c}\text { Question: «Most } \\
\text { serious obstacle } \\
\text { affecting the } \\
\text { operation of this } \\
\text { establishment» }\end{array}$} & \multicolumn{2}{|c|}{$\begin{array}{c}\text { Overall list } \\
\text { of } 29 \text { countries }\end{array}$} & \multicolumn{2}{|c|}{$\begin{array}{c}\text { Selected } \\
\text { countries }\end{array}$} \\
\cline { 2 - 5 } quency & Percent & $\begin{array}{c}\text { Fre- } \\
\text { quency }\end{array}$ & Percent \\
\hline Tax rates & 2257 & 16,14 & 1176 & 15,15 \\
\hline Access to finance & $\mathbf{1 9 0 5}$ & $\mathbf{1 3 , 6 2}$ & $\mathbf{9 9 2}$ & $\mathbf{1 2 , 7 8}$ \\
\hline $\begin{array}{l}\text { Competition from } \\
\text { the informal sector }\end{array}$ & 1471 & 10,52 & 905 & 11,66 \\
\hline Political instability & 1323 & 9,46 & 892 & 11,49 \\
\hline $\begin{array}{l}\text { Inadequately edu- } \\
\text { cated workforce }\end{array}$ & 1287 & 9,20 & 814 & 10,49 \\
\hline Corruption & 799 & 5,71 & 439 & 5,66 \\
\hline Does not apply & 700 & 5,01 & 356 & 4,59 \\
\hline $\begin{array}{l}\text { Crime, theft and } \\
\text { disorder }\end{array}$ & 676 & 4,83 & 163 & 2,10 \\
\hline Electricity & 600 & 4,29 & 306 & 3,94 \\
\hline Don't know & 583 & 4,17 & 411 & 5,30 \\
\hline Other Obstacle & 2873 & 20,55 & 1307 & 16,84 \\
\hline Total & 13983 & 100,00 & 7761,00 & 100,00 \\
\hline
\end{tabular}

Source: BEEPS

banks making loans are concerned not only about the interest rate that they charge on the loan but also about the riskiness of the loan. Also, the interest rate the bank charges may itself affect the riskiness of the pool of loans, either by attracting high-risk borrowers (adverse selection effect) or by adversely affecting the actions and incentives of borrowers (moral hazard effect). Moreover, the price of credit can also be the barrier. Even when supply and demand do intersect, the equilibrium price for a loan (including the fees and minimum requirements) may be too high, making them unaffordable for a large proportion of potential borrowers. In this case, there is no rationing but it still leads to financial exclusion.

Besides the significance of access to finance for economic development, the main hypothesis that we examine in this paper is that the persistent unequal access to finance may determine the economic structure in a way that it can impact the macroeconomic stability. The evidence from Latin America shows that financial liberalization in the 1990s had led to changes in trade patterns as the non-tradable sector had been the privileged recipient of foreign funds (Fanelli and Keifman, 2002). During economic 
transition in CEE, some sectors were more significant receivers of credit fuelled from financial integration and foreign inflows than others. The last refers particularly to the real estate and construction sectors that became important drivers of economic growth in many countries (Transition report, 2010, p. 45). That in turn contributed to inflation in asset prices as the share of construction in total value significantly added an increase in almost all transition countries from 2000 to 2007, while house prices also surged in correlation with credit growth.

Financial integration, reflected in significant foreign direct investment and foreign debt inflows following the initial financial liberalization, was directly connected to a widening of the current account gap as well as to the income convergence of these economies. With the global financial crisis, the applied growth model in transition economies that was based on financial integration and the import of foreign savings has come under question as, in parallel with economic growth, it was responsible for the accumulation of many macroeconomic vulnerabilities. Since the crisis, there is a raising awareness with economic policy designers on the need to improve domestic export capacity and competitiveness across the region. The problematic in defining the new sustainable pillars of economic growth in European transition economies that is coherent with macroeconomic stability remains a big challenge for future research as well as finding credible sources of growth. The main problematic consists in controlling fiscal and current account deficits and providing sustainable growth.

For a reduction of the current account deficit, the tradable sector of the economy is particularly important - to provide growth through rise in net export. One of the possible factors behind large underperformance of export versus import may be found in a Dutch disease-like effect. Namely, it was strongly possible that large financial inflows were contributing constantly to real appreciation of local currencies in the countries of Emerging Europe before the crisis. The last could have reflected in the underdevelopment of tradable goods production contributing to current account gaps.

The idea of this paper is to examine the financing obstacle of enterprises across the region of Emerging Europe. The approach consists of analyzing the access to finance and other financing terms. The main determinants of access to finance (financing obstacle) are examined using probit estimation based on data from the enterprise level survey (BEEPS). It is of primary interest to determine the firm level characteristics effect on the degree of the financing obstacle. Particular attention is placed on the effect of the industry sector (manufacturing industry versus other industries) in order to formulate the hypothesis on the effects of the financing obstacle on the overall economic structure and trade deficit. In what follows, we first we present the data base followed by the estimation methodology and results in section. The discussion of results is given in the last section.

Description of the database. In order to examine the determinants of a firm's access to finance and relationship between access to finance and sector of activity, we use the enterprise level data from the Business Environment and Enterprise Performance Survey (BEEPS) (Bancel, 1999; Vemimmen, 2006).

The firm level data from BEEPS is combined with country level macroeconomic and financial sector data from EBRD, World Bank, and IMF data basis. These data include per capita GDP, current account deficit, credit to GDP, EBRD transition and financial reforms indices, and share of foreign banks. The aim of use of this kind of country level data is to obtain additional quality of the access to finance determinants.

The sample was structured to be representative for each country with specific quotas in terms of region, sector and enterprise size using the variable 'Total sales'. The number of firms covered is roughly proportional to the number of firms in the country, ranging from 260 in Albania to 1592 in Poland. The survey tried to achieve representativeness in terms of the size of the firms it surveyed: between three quarters and nine tenths of the firms surveyed are "small" (less than 20 workers) and only around $5 \%$ of the firms surveyed are "large" (more than 100 workers). The survey also aimed to achieve representativeness in terms of private vs. public firms, firms with access to foreign product markets, and firms which receive government subsidies.

For the purpose of our analysis of the credit constraint determinants, we base the estimated model on the three turns of the survey, namely 2002, 2005 and 2008, where the 2008 turn was actually held during late 2007 and during 2008 and 2009, depending on the country. Since the content of the questionnaire in each survey was modified, in order to test the homogenous set of variables we base the unbalanced panel data provided by the EBRD that includes consolidation of the consistent part of the questionnaire over turns of the survey. Out of 29 transition countries from Europe and Asia, the dataset is reduced to 18 European transition economies (Bosnia, Bulgaria, Croatia, Czech Republic, Estonia, FYROM, Hungary, Latvia, Lithuania, Moldova, Montenegro, Poland, Romania, Serbia, Slovakia, Slovenia, Ukraine). 


\section{Estimation methodology, variables definition and results}

Both in testing the determinants of the access to finance as obstacle and in testing the loan demand, we use the probit estimation technique and estimate the model of the following form:

$$
Y_{i}=\alpha+\beta X_{i}+\lambda S_{i}+\gamma F_{i}+\delta C_{i}+\mu T_{i}+\varepsilon
$$

with $i=1, \ldots, N$ where $N$ denotes the number of firms. $Y$ is the dummy variable constructed to capture the firm's financial constraint in the first set of estimations while in the second part of the estimations it refers to dummy variables that capture demand for loans. Details on the construction of dependent variable alternatives are presented in the next subsection and in the appendix to this paper (see Table 2). $X$ represents the vector of firm characteristics that includes size, age, percentage of sales exported, foreign ownership, government ownership, variable capturing ISO certification, and dummy variable for audited financial statements. The $X$ vector also includes measure of firm performance such as employment growth as well as market position captured by the pressures from competition and from customers that are observed by the firms. $S$ stands for a sector dummy which is the main variable of interest. $F$ represents a vector of country level characteristics such as financial development, overall level of credit risk, advancement in banking sector reforms and real GDP growth. $C$ is the vector of country dummies for 17 (out of 18) countries covered by the survey. $T$ represents the dummy variable that controls for the timing of the survey. In that respect, in the estimation results presented in this study, we use only the crisis dummy to control for the financial crisis effect on the overall access to finance resulting from a sudden credit crunch. eis the error term. The construction of the dependent variables is presented in Table 2.

Indicators of access to finance. In order to estimate the determinants of financial constraint, we constructed two alternative indicators: Access_to_ finance_1 and Access_to_finance_ 2 based on the available data from the survey. We consider both indicators as good proxies for financial obstacle. The first has better coverage in terms of time as it is represented in all turns of the BEEPS survey $(17,758$ observations), while the second is included only in last two turns (7,751 observations). The dependent variable (LHS) Access_to_finance_1 is a dummy,

Table 2. Definitions of dependent variables

\begin{tabular}{|c|c|}
\hline Dependent variable name & Definition \\
\hline Access to finance_1 & $\begin{array}{l}\text { Question: "Is Access to finance, which includes availability and cost, interest rates, fees and } \\
\text { collateral requirements, No Obstacle, a Minor Obstacle, a Moderate Obstacle, a Major } \\
\text { Obstacle, or a Very Severe Obstacle to the current operations of this establishment?", dummy } \\
\text { variable = } 1 \text { for Major Obstacle and Very Severe Obstacle, and }=0 \text { for other answers }\end{array}$ \\
\hline Access to finance_2 & $\begin{array}{l}\text { Question: "Which of the following elements of the business environment, if any, currently } \\
\text { represents the biggest obstacle faced by this establishments." Dummy variable }=1 \text { for Access } \\
\text { to finance, and }=0 \text { for all other elements answered: Access to land, Business licensing and } \\
\text { permits, Corruption, Courts, Crime, theft and disorder, Customs and trade regulations, } \\
\text { Electricity, Inadequately educated workforce, Labor regulations, Political instability, Practices } \\
\text { of competitors in the informal sector, Tax administration, Tax rates, Transport }\end{array}$ \\
\hline Have_loan & $\begin{array}{l}\text { Dummy }=1 \text { if at the time of the survey the establishment have a line of credit or a loan from a } \\
\text { financial institution, }=0 \text { if not }\end{array}$ \\
\hline No_need_loan & $\begin{array}{l}\text { Question: "What was the main reason why this establishment did not apply for any line of } \\
\text { credit or loan in /fiscal year preceding the survey/?", Dummy variable =1 for answer "No need } \\
\text { for a loan - establishment has sufficient capital" }\end{array}$ \\
\hline $\begin{array}{l}\text { Interest_rates_not_ } \\
\text { favorable }\end{array}$ & $\begin{array}{l}\text { Question: "What was the main reason why this establishment did not apply for any line of } \\
\text { credit or loan in /fiscal year preceding the survey/?", Dummy variable }=1 \text { for answer "Interest } \\
\text { rates are not favorable", =0 for all other answers. Variable covers only the subsample of firms } \\
\text { with answers to this question different from "No need for a loan -- establishment has sufficient } \\
\text { capital" }\end{array}$ \\
\hline $\begin{array}{l}\text { Not_favourable_loan_ } \\
\text { terms }\end{array}$ & $\begin{array}{l}\text { Question: "What was the main reason why this establishment did not apply for any line of } \\
\text { credit or loan in /fiscal year preceding the survey/?", Dummy variable }=1 \text { for answer "Interest } \\
\text { rates are not favorable" or " Collateral requirements are too high" or "Size of loan and maturity } \\
\text { are insufficient", }=0 \text { for all other answers. Variable covers only the subsample of firms with } \\
\text { answers to this question different from "No need for a loan -- establishment has sufficient } \\
\text { capital" }\end{array}$ \\
\hline
\end{tabular}


which equals 1 if the firm qualified its degree of the access to finance obstacle (which includes availability and cost, interest rates, fees, and collateral requirements) as a 'major obstacle' or a 'very severe obstacle' for the establishment's current operations. It equals 0 for the qualifications: 'no obstacle', 'minor obstacle', or 'moderate obstacle'.

We use another alternative dependent variable for capturing the measure of a firm's financial constraint, Access_to_finance_2. It is constructed from the question in which the firm manager is asked about his major obstacle in the business environment. It equals 1 if, among the various alternative answers offered as business obstacles, a firm chooses 'access to finance' as the major one. It equals 0 for any other stated answer from the list.

Indicators of demand for loans. In order to get more insight into demand for loans, four additional dependent variables are extracted from the survey. These are: Have loan, No need loan, Interest rate_not_favorable, and Not_favorable_loan_terms. Have_loan is a dummy variable that equals 1 if a company has a loan or credit line in use at the time of the survey, and 0 otherwise. The following three dependent variables that we use are derived from two related questions from the survey. First is "Did this establishment apply for any line of credit or loan in the fiscal year preceding the survey?" If a firm stated that it did not apply for a loan or a line of credit, than it was asked another question regarding the main reason for that: «What was the main reason why this establishment did not apply for any line of credit or loan in the fiscal year preceding the survey?». The variable No_need_loan is constructed in a way that it equals 1 if the company stated that the main reason for not using a loan is that it had no need to take a loan. The last two variables relate to the same question but to another two options. The variable Interest_rate_not_favorable is a dummy deducted from the answer that company considers that interest rates are not favorable. Not favorable loan terms refers to the answer that other loan terms are not favorable such as maturity, size of loan, and collateral requirements.

Definition of independent variables. Among the explanatory variables, our main variable of interest in this research is the variable Manufacturing. It is a dummy derived from the answers to the question on the activity sector of the enterprise, as observed by the interviewer. Since there is often the discordance between the declared industry sector of a company and the factual industry sector of its core operations, we find it more objective to use the observed sector as more probably corresponding to the effective business of the surveyed firm. It equals 1 if the firm operates in the manufacturing industry while all other business sectors are treated as 0 . They include: construction, transport, wholesale and retail trade, information technology, and hotels and restaurants. The summarized statistic on the distribution of dependent variables describing financing obstacle (Access_to finance_l 1 and Access_to finance 2) across categories of the industry sector (variable Manufacturing) depicts more frequent problems in access to finance within manufacturing businesses than within other industries, Table 3 . All other independent variables are explained in Table 4.

Table 3. Access to finance obstacle vs. industry, overview of database

\begin{tabular}{|l|r|r|r|r|r|r|}
\hline & \multicolumn{1}{|c|}{$\begin{array}{c}\text { Manufacturing } \\
\text { business }\end{array}$} & \multicolumn{1}{c|}{$\begin{array}{c}\text { Other industries (non- } \\
\text { manufacturing) }\end{array}$} & \multicolumn{2}{c|}{ All sectors } \\
\cline { 2 - 7 } & $\begin{array}{c}\text { Number } \\
\text { of obs. }\end{array}$ & $\begin{array}{c}\text { Share } \\
\text { in Total, } \\
\text { in \% }\end{array}$ & $\begin{array}{c}\text { Number } \\
\text { of obs. }\end{array}$ & $\begin{array}{c}\text { Share } \\
\text { in Total, } \\
\text { in \% }\end{array}$ & $\begin{array}{c}\text { Number of } \\
\text { obs. }\end{array}$ & $\begin{array}{c}\text { Share } \\
\text { in Total, } \\
\text { in \% }\end{array}$ \\
\hline $\begin{array}{l}\text { Access to finance is Major obstacle or } \\
\text { Very sever obstacle }\end{array}$ & 1,613 & $\mathbf{2 4}$ & 2,251 & 20 & 3,864 & 22 \\
\hline $\begin{array}{l}\text { Access to finance is Moderate obstacle, } \\
\text { Minor obstacle of Not an obstacle }\end{array}$ & 5,035 & 76 & 8,859 & 80 & 13,894 & 78 \\
\hline Total Access to finance_1 & $\mathbf{6 , 6 4 8}$ & $\mathbf{1 0 0}$ & $\mathbf{1 1 , 1 1 0}$ & $\mathbf{1 0 0}$ & $\mathbf{1 7 , 7 5 8}$ & $\mathbf{1 0 0}$ \\
\hline $\begin{array}{l}\text { Access to finance is the major business } \\
\text { obstacle }\end{array}$ & 501 & $\mathbf{1 5}$ & 501 & 11 & 1,002 & 13 \\
\hline $\begin{array}{l}\text { Access to finance is not the major } \\
\text { business obstacle }\end{array}$ & 2,752 & 85 & 3,997 & 89 & 6,749 & 87 \\
\hline Total Access to finance_2 & $\mathbf{3 , 2 5 3}$ & $\mathbf{1 0 0}$ & $\mathbf{4 , 4 9 8}$ & $\mathbf{1 0 0}$ & $\mathbf{7 , 7 5 1}$ & $\mathbf{1 0 0}$ \\
\hline
\end{tabular}




\section{Table 4. Definition of independent variables}

\begin{tabular}{|c|c|}
\hline Variable & Definition \\
\hline Manufacturing_dummy & $\begin{array}{l}\text { Dummy variable equals } 1 \text { if the firm operates in the manufacturing industry and } \\
\text { equals } 0 \text { for services firms }\end{array}$ \\
\hline Large & $\begin{array}{l}\text { Dummy variable equals } 1 \text { for firms with } 100 \text { and more employees and } 0 \text { for less } \\
\text { than } 100\end{array}$ \\
\hline Small & Dummy variable equals 1 for firms with 19 and less employees \\
\hline Sales_exported & $\%$ share of total sales that is exported \\
\hline Foreign_capital & Percent of the firm owned by foreign individuals, companies or organizations \\
\hline State_capital & Percent of the firm owned by Government/State \\
\hline Overdue_utilities_taxes & $\begin{array}{l}\text { Dummy variable assigned a value } 1 \text { if the establishment currently have any } \\
\text { payments overdue by more than } 90 \text { days for utilities or taxes, zero otherwise }\end{array}$ \\
\hline Ln_old & Log of the age of operations of the firm \\
\hline Pressure_domestic_competitors & $\begin{array}{l}\text { Dummy assigned } 1 \text { if pressure from domestic competitors is affecting the firm's } \\
\text { decisions to develop new products or services and markets is qualified as very } \\
\text { important or fairly important, zero otherwise }\end{array}$ \\
\hline Pressure_foreign_competitors & $\begin{array}{l}\text { Dummy assigned } 1 \text { if pressure from foreign competitors is affecting the firm's } \\
\text { decisions to develop new products or services and markets is qualified as very } \\
\text { important or fairly important, zero otherwise }\end{array}$ \\
\hline Pressure_customers & $\begin{array}{l}\text { Dummy assigned } 1 \text { if pressure from customers is affecting the firm's decisions } \\
\text { to develop new products or services and markets is qualified as very important } \\
\text { or fairly important, zero otherwise }\end{array}$ \\
\hline Audited_financial_statements & Dummy assigned 1 if \\
\hline Quality_certificate & $\begin{array}{l}\text { Dummy assigned } 1 \text { if the firm has an internationally-recognized quality } \\
\text { certification, zero otherwise }\end{array}$ \\
\hline Employees_growth & $\begin{array}{l}\text { Growth rate of the number of employees between previous fiscal year and } 3 \text { years } \\
\text { before the previous fiscal year }\end{array}$ \\
\hline Crisis_dummy & $\begin{array}{l}\text { Dummy variable assigned a value } 1 \text { for the time of the interview falling in } \\
2008: q 4 \text { and in } 2009,0 \text { otherwise }\end{array}$ \\
\hline Ln_GDP_per_capita & $\begin{array}{l}\text { Logarithm of the respective country per capita GDP in the year preceding the } \\
\text { survey }\end{array}$ \\
\hline Ln_nr_banks & Logarithm of the number of banks in the respective country \\
\hline Credit_to_GDP & Credit to private sector, in $\%$ of GDP \\
\hline NPL & Non-performin loans, in \% of total loan \\
\hline Foreign_banks_share & Share of assets held by foreign banks in total banking sector assets, in \% \\
\hline CA & $\begin{array}{l}\text { Current account balance, in \% of GDP. Positive for surplus and negative values } \\
\text { for deficit }\end{array}$ \\
\hline EBRD_banking_reform_4 & $\begin{array}{l}\text { Dummy variable assigned } 1 \text { for value } 4 \text { of EBRD indicator of bankimg sector } \\
\text { reform, zero otherwise }\end{array}$ \\
\hline
\end{tabular}

\section{Results from the empirical estimation}

Based on the described database, methodology and constructed variables, we obtain the following estimation results on determinants of financial constraint and we describe some characteristics of demand for loans.

Results for determinants of financial constraint. The estimation strategy consists of the following. First we examine the determinants of firm financial constraint using the variable for financial constraint. We rerun the regression using two alternative dependent variables (Access_to_finance_1 and Access_to_finance_2). The results for the estimation of the variable Access_to_finance_l is presented in Table 5 and Table 6 . Further on, we test the financial obstacle determinants for the subset of firms that do not use any loan or line of credit (condition that variable Have loan is equal 0) in order to get a bit sharper view on the population of firms that are practical out of the credit market. Parts of these firms are simply rationed by banks as too risky. The others do not need external financing while some of them perceive loan supply as inappropriate for their needs. By doing this estimation we try to extract the firm characteristics that increase probability to face financial obstacle. In that way we may describe which kind of companies are more likely to be rationed. We control for all available firm characteristics, as in estimation on full sample. The results are presented in Table 9. 
Table 5. Probit model: Dependent variable: Access_to_finance_1, marginal effects

\begin{tabular}{|c|c|c|c|c|c|c|c|c|}
\hline Variable & (1) & (2) & (3) & (4) & (5) & (6) & (7) & (8) \\
\hline Manufacturing_dummy & $0.032 * * *$ & $0.049 * * *$ & $0.050 * * *$ & $0.052 * * *$ & $0.051^{* * *}$ & $0.051 * * *$ & $0.054 * * *$ & $0.039 * * *$ \\
\hline Large & $-0.030 * * *$ & $-0.022 * *$ & $-0.022 * *$ & $-0.020^{* *}$ & $-0.020 * *$ & $-0.022 * *$ & -0.017 & $-0.026^{* * *}$ \\
\hline Small & $0.022 * * *$ & $0.018 * *$ & $0.014 *$ & 0.014 & 0.013 & $0.014^{*}$ & 0.012 & $0.016^{*}$ \\
\hline Sales_exported & $0.000^{* *}$ & 0.000 & 0.000 & 0.000 & 0.000 & 0.000 & 0.000 & 0.000 \\
\hline Foreign_capital & $-0.001 * * *$ & $-0.001 * * *$ & $-0.001 * * *$ & $-0.001 * * *$ & $-0.001 * * *$ & $-0.001 * * *$ & $-0.001 * * *$ & $-0.001 * * *$ \\
\hline State_capital & 0.000 & 0.000 & 0.000 & 0.000 & 0.000 & 0.000 & 0.000 & 0.000 \\
\hline Overdue_utilities_taxes & $0.148^{* * *}$ & $0.132 * * *$ & $0.134 * * *$ & $0.132 * * *$ & $0.136^{* * *}$ & $0.126^{* * *}$ & $0.113^{* * *}$ & $0.146^{* * *}$ \\
\hline Ln_old & 0.003 & 0.008 & 0.005 & 0.005 & 0.004 & 0.003 & 0.002 & 0.002 \\
\hline $\begin{array}{l}\text { Pressure domestic } \\
\text { competitors }\end{array}$ & $0.025^{* * *}$ & $0.025^{* * *}$ & $0.023^{* * *}$ & $0.023^{* *}$ & $0.022 * *$ & $0.018^{* * *}$ & $0.023^{* *}$ & $0.021 * *$ \\
\hline $\begin{array}{l}\text { Pressure foreign } \\
\text { competitors }\end{array}$ & $0.040 * * *$ & $0.043^{* * *}$ & $0.043 * * *$ & $0.042 * * *$ & $0.043^{* * *}$ & $0.042^{* * *}$ & $0.036^{* * *}$ & $0.045^{* * *}$ \\
\hline Pressure_customers & 0.003 & 0.002 & 0.002 & 0.002 & 0.002 & 0.001 & 0.003 & 0.000 \\
\hline $\begin{array}{l}\text { Audited_financial } \\
\text { _statements }\end{array}$ & $-0.013^{*}$ & $-0.033^{* * *}$ & $-0.035 * * *$ & $-0.037 * * *$ & $-0.038 * * *$ & $-0.029 * * *$ & $-0.033^{* * *}$ & $-0.029 * * *$ \\
\hline Quality_certification & 0.005 & 0.010 & 0.005 & 0.005 & 0.005 & 0.007 & 0.007 & 0.004 \\
\hline Employees_growth & $-0.020^{* * *}$ & $-0.027 * * *$ & $-0.024 * * *$ & $-0.024 * * *$ & $-0.024 * * *$ & $-0.027^{* * *}$ & $-0.024 * * *$ & $-0.019 * * *$ \\
\hline Crises_dummy & $0.039^{* * *}$ & $0.026^{* * *}$ & $0.018^{* *}$ & $0.020^{* *}$ & $0.017 * *$ & $0.018^{* *}$ & $0.019^{* *}$ & $0.036^{* * *}$ \\
\hline Ln_GDP_per_capita & & $-0.034 * * *$ & & & & & & \\
\hline Foreign_banks_share & & & $-0.001 * * *$ & & & & & \\
\hline Credit_to_GDP & & & & $-0.001 * * *$ & & & & \\
\hline CAD & & & & & $-0.001 * * *$ & & & \\
\hline $\begin{array}{l}\text { EBRD_banking } \\
\text { reform_4 }\end{array}$ & & & & & & $-0.072 * * *$ & & \\
\hline NPL & & & & & & & $0.002 * * *$ & \\
\hline Ln_nr_banks & & & & & & & & $0.072 * * *$ \\
\hline Observations & 15,199 & 14,548 & 14,541 & 14,541 & 14,548 & 14,524 & 13,753 & 14,541 \\
\hline Prob>chi2 & 0.0000 & 0.0000 & 0.0000 & 0.0000 & 0.0000 & 0.0000 & 0.0000 & 0.0000 \\
\hline pseudo R2 & 0.05 & 0.03 & 0.03 & 0.03 & 0.03 & 0.03 & 0.02 & 0.04 \\
\hline
\end{tabular}

$* \mathrm{p}<0.1 ; * * \mathrm{p}<0.05 ; * * * \mathrm{p}<0.01$.

Table 6. Probit model: Dependent variable: Access_to_finance_2, marginal effects

\begin{tabular}{|l|c|c|c|c|c|c|c|c|}
\hline \multicolumn{1}{|c|}{ Variable } & $\mathbf{( 1 )}$ & $\mathbf{( 2 )}$ & $\mathbf{( 3 )}$ & $\mathbf{( 4 )}$ & $\mathbf{( 5 )}$ & $\mathbf{( 6 )}$ & $\mathbf{( 7 )}$ & $\mathbf{( 8 )}$ \\
\hline Manufacturing_dummy & $0.032^{* * *}$ & $0.049^{* * *}$ & $0.050^{* * *}$ & $0.052^{* * *}$ & $0.051^{* * *}$ & $0.051^{* * *}$ & $0.054^{* * *}$ & $0.039^{* * *}$ \\
\hline Large & $-0.030^{* * *}$ & $-0.022^{* *}$ & $-0.022^{* *}$ & $-0.020^{*}$ & $-0.020^{* *}$ & $-0.022^{* *}$ & -0.017 & $-0.026^{* * *}$ \\
\hline Small & $0.022^{* * *}$ & $0.018^{* *}$ & $0.014^{*}$ & $0.014^{*}$ & 0.013 & $0.014^{*}$ & 0.012 & $0.016^{*}$ \\
\hline Sales_exported & $0.000^{* *}$ & 0.000 & 0.000 & 0.000 & 0.000 & 0.000 & 0.000 & 0.000 \\
\hline Foreign_capital & $-0.001^{* * *}$ & $-0.001^{* * *}$ & $-0.001^{* * *}$ & $-0.001^{* * *}$ & $-0.001^{* * *}$ & $-0.001^{* * *}$ & $-0.001^{* * *}$ & $-0.001^{* * *}$ \\
\hline State_capital & 0.000 & 0.000 & 0.000 & 0.000 & 0.000 & 0.000 & 0.000 & 0.000 \\
\hline Overdue_utilities_taxes & $0.148^{* * *}$ & $0.132^{* * *}$ & $0.134^{* * *}$ & $0.132^{* * *}$ & $0.136^{* * *}$ & $0.126^{* * *}$ & $0.113^{* * *}$ & $0.146^{* * *}$ \\
\hline Ln_old & 0.003 & 0.008 & 0.005 & 0.005 & 0.004 & 0.003 & 0.002 & 0.002 \\
\hline $\begin{array}{l}\text { Pressure_domestic } \\
\text { competitors }\end{array}$ & $0.025^{* * *}$ & $0.025^{* * *}$ & $0.023^{* * *}$ & $0.023^{* *}$ & $0.022^{* *}$ & $0.018^{* *}$ & $0.023^{* *}$ & $0.021^{* *}$ \\
\hline $\begin{array}{l}\text { Pressure_foreign } \\
\text { competitors }\end{array}$ & $0.040^{* * *}$ & $0.043^{* * *}$ & $0.043^{* * *}$ & $0.042^{* * *}$ & $0.043^{* * *}$ & $0.042^{* * *}$ & $0.036^{* * *}$ & $0.045^{* * *}$ \\
\hline
\end{tabular}




\begin{tabular}{|c|c|c|c|c|c|c|c|c|}
\hline \multicolumn{9}{|c|}{ Продовження табл. 6} \\
\hline Variable & (1) & (2) & (3) & (4) & (5) & (6) & (7) & (8) \\
\hline Pressure_customers & 0.003 & 0.002 & 0.002 & 0.002 & 0.002 & 0.001 & 0.003 & 0.000 \\
\hline $\begin{array}{l}\text { Audited_financial } \\
\text { _statements }\end{array}$ & $-0.013 *$ & $-0.033 * * *$ & $-0.035^{* * *}$ & $-0.037 * * *$ & $-0.038 * * *$ & $-0.029 * * *$ & $-0.033 * * *$ & $-0.029 * * *$ \\
\hline Quality_certification & 0.005 & 0.010 & 0.005 & 0.005 & 0.005 & 0.007 & 0.007 & 0.004 \\
\hline Employees_growth & $-0.020 * * *$ & $-0.027 * * *$ & $-0.024 * * *$ & $-0.024 * * *$ & $-0.024 * * *$ & $-0.027 * * *$ & $-0.024 * * *$ & $-0.019 * * *$ \\
\hline Crises_dummy & $0.039 * * *$ & $0.026^{* * *}$ & $0.018^{* *}$ & $0.020 * *$ & $0.017 * *$ & $0.018 * *$ & $0.019 * *$ & $0.036^{* * *}$ \\
\hline Ln_GDP_per_capita & & $-0.034 * * *$ & & & & & & \\
\hline Foreign_banks_share & & & $-0.001 * * *$ & & & & & \\
\hline Credit_to_GDP & & & & $-0.001 * * *$ & & & & \\
\hline CAD & & & & & $-0.001 * * *$ & & & \\
\hline $\begin{array}{l}\text { EBRD_banking } \\
\text { reform_4 }\end{array}$ & & & & & & $-0.072 * * *$ & & \\
\hline NPL & & & & & & & $0.002 * * *$ & \\
\hline Ln_nr_banks & & & & & & & & $0.072 * * *$ \\
\hline Observations & 15,199 & 14,548 & 14,541 & 14,541 & 14,548 & 14,524 & 13,753 & 14,541 \\
\hline Prob>chi2 & 0.0000 & 0.0000 & 0.0000 & 0.0000 & 0.0000 & 0.0000 & 0.0000 & 0.0000 \\
\hline pseudo R2 & 0.05 & 0.03 & 0.03 & 0.03 & 0.03 & 0.03 & 0.02 & 0.04 \\
\hline
\end{tabular}

$* \mathrm{p}<0.1 ; * * \mathrm{p}<0.05 ; * * * \mathrm{p}<0.01$

Table 7. Distribution of observation of 'Access to finance' as business obstacle across firms split by their use of loan financing

\begin{tabular}{|l|c|c|c|c|c|c|}
\hline \multirow{2}{*}{ Definition } & \multicolumn{2}{|c|}{ Have a loan } & \multicolumn{2}{c|}{ Do not have a loan } & \multicolumn{2}{c|}{ Total } \\
\cline { 2 - 7 } & $\begin{array}{c}\text { Number } \\
\text { of obs. }\end{array}$ & $\begin{array}{c}\text { Share } \\
\text { in Total, \% }\end{array}$ & $\begin{array}{c}\text { Number } \\
\text { of obs. }\end{array}$ & $\begin{array}{c}\text { Share } \\
\text { in Total, \% }\end{array}$ & $\begin{array}{c}\text { Number } \\
\text { of obs. }\end{array}$ & $\begin{array}{c}\text { Share } \\
\text { in Total, \% }\end{array}$ \\
\hline $\begin{array}{l}\text { Access to finance is Major obstacle or Very } \\
\text { sever obstacle }\end{array}$ & 1,031 & 25 & 726 & 20 & 1,757 & 23 \\
\hline $\begin{array}{l}\text { Access to finance is Moderate obstacle, } \\
\text { Minor obstacle of Not an obstacle }\end{array}$ & 3,074 & 75 & 2,824 & 80 & 5,898 & 77 \\
\hline Total Access to finance_1 & $\mathbf{4 , 1 0 5}$ & $\mathbf{1 0 0}$ & $\mathbf{3 , 5 5 0}$ & $\mathbf{1 0 0}$ & $\mathbf{7 , 6 5 5}$ & $\mathbf{1 0 0}$ \\
\hline $\begin{array}{l}\text { Access to finance is the major business } \\
\text { obstacle }\end{array}$ & 648 & 16 & 347 & 10 & 995 & 13 \\
\hline $\begin{array}{l}\text { Access to finance is not the major business } \\
\text { obstacle }\end{array}$ & 3,457 & 84 & 3,203 & 90 & 6,660 & 87 \\
\hline Total Access to finance_2 & $\mathbf{4 , 1 0 5}$ & $\mathbf{1 0 0}$ & $\mathbf{3 , 5 5 0}$ & $\mathbf{1 0 0}$ & $\mathbf{7 , 6 5 5}$ & $\mathbf{1 0 0}$ \\
\hline
\end{tabular}

Source: BEEPS

By running the probit model, we garner strong evidence that the fact that an enterprise operates in the manufacturing industry increases the probability that the enterprise faces the access to finance in all specification of the model. The same finding holds on the sub-sample of firms that do not use any loan or credit line in the time of the survey after controlling for all relevant enterprise characteristics including those that control for a firm's risk and, therefore, the possibility that it is simply rationed by banks. It is not likely that the fact that a company operates in the manufacturing business impacts per se the risk of the business. The significant coefficient for Manufacturing in this case may imply that for some other reason the companies in production of tradable goods are relatively more financially constrained than firms in other industries, such as services. The last hypothesis holds only if both manufacturing and 
other industries' average risk is at a similar level so that the estimation result is not an outcome of the fact that banks ration more manufacturing businesses due to their relatively higher risk than in other industries. We have however controlled for all determinants of risk of a firm that are observable from the available data from the survey.

Other results from the estimation related to controlling the marginal effects of the variables to the probability that a company faces access to finance as an obstacle are mostly in line with the intuition. We arrived at the expected result that small enterprises have more difficulties in accessing finance than medium ones. Similarly, large enterprises are in a more favorable position than medium and small ones. The last is in line with the literature on SME financing such as Beck and Demirguc-Kunt (2006). The fact that a company exports a larger share of its sales does not have a significant impact to its access to finance. Foreign owned companies have less severe financial constraint then domestic ones. State ownership apparently has no effect on a company's access to finance. In the model specifications using Access_to_finance_1 the coefficients with State capital are not significant, while in models with Access_to_finance_2 as dependent variable, the coefficient is positive and significant at $10 \%$ or at $5 \%$ in some specifications while its value is very low. This finding is in line with intuition that some state companies may have easier access to finance and some others may have it more difficult in comparison to private ones. Another intuitively expected finding is that companies with liquidity problems (overdue payments of utilities and taxes) would face higher probability of being financially constrained.

A company's age has no statistically significant effect on its access to finance. The fact that a company had its financial statements audited by an independent auditor eases its access to finance in models using the first version of the dependent variable with larger coverage while the alternative version of the dependent variable is not influenced by the variable Audited financial_statements. Possession of quality certificates has no effect on access to finance according to the estimation results. Employees growth as a variable that is a proxy for a firm's performance has negative and statistically significant coefficient in models with the dependent variable Access_to_finance_1, while coefficients are not significant in any specification using Access_to_finance_2 as RHS variable. Market pressures that a company faces from competitors, both domestic and foreign, increases the probability of a firm's financial constraint in the model using the first alternative of the dependent variable while in the second alternative it has no statistical significance.
We also control for macroeconomic characteristics as there are 18 countries in the sample with different shapes of their financial systems and economies. These results have shown that companies in countries with higher per capita income and a higher EBRD grade in banking sector reforms and higher level of credit to GDP (only in models with Access_ to finance_2 as dependent variable) face less probability to encounter financing obstacles. Firms in countries with a higher non-performing loans level face greater financing obstacles. The number of banks has the opposite sign in two specifications of the model using alternative proxies for financing obstacles while the higher level of GDP per capita reduces the probability that the firm faces financing obstacles in the model with Access_to_finance_1 as the dependent variable while the coefficient is positive but not significant in the model with Access_to finance_2 as the dependent variable. Crisis dummy in some specification had statistically significant and positive marginal impact on firm-level financial constraint probability. We control for country dummies.

Results for determinants of loan demand. We also test for the characteristics of the probability that a firm uses a loan or a credit line by running the probit model using as dependent variable Have loan and testing for all relevant firm characteristics. This exercise gives some insight into the shape of the demand for loans that is financed by banks, i.e., that are not constrained on external financing loans and credit lines. In order to test the characteristics of the unconstrained firms which do not appear in the demand for loans, we run the probit model estimation using No_need loan as LHS variable. Additionally, we analyze the determinants of the probability that a firm declares the price barrier in access to finance, using Interest_rates_not_favorable. Finally, we add another barrier aside from the price obstacle. We test for other terms of loan supply that are perceived as not favorable and that leaves firms out of demand for loans. The dependent variable relates to the terms of loan supply: 'loan size or maturity is insufficient' and 'collateral requirements are too high' translated into dummy variable Not_favorable_loan_terms. The results of the estimation are presented in Table 9.

From the summary of answers on reasons for not applying for a loan or a credit line, across the variable Manufacturing, presented in Table 8, we already record the less represented answer that a firm does not need a loan, with $66.8 \%$ for manufacturing businesses against the $72.9 \%$ of other industries, on the sample of 6,966 firms from the transition countries in Europe that did not apply for a loan in the year prior to the year of the survey. 
Table 8. Distribution of answers on reasons why firm did not apply for a loan or a credit line - by business sector (manufacturing and other industries)

\begin{tabular}{|c|c|c|c|c|c|c|}
\hline \multirow{2}{*}{$\begin{array}{l}\text { «What was the main reason why this } \\
\text { establishment did not apply for any line } \\
\text { of credit or loan in fiscal year preceding } \\
\text { the year of survey?» }\end{array}$} & \multicolumn{2}{|c|}{ Manufacturing business } & \multicolumn{2}{|c|}{$\begin{array}{l}\text { Other industries (non- } \\
\text { manufacturing) }\end{array}$} & \multicolumn{2}{|c|}{ All sectors } \\
\hline & $\begin{array}{l}\text { Number } \\
\text { of obs. }\end{array}$ & $\begin{array}{c}\text { Share } \\
\text { in Total, } \%\end{array}$ & $\begin{array}{l}\text { Number } \\
\text { of obs. }\end{array}$ & $\begin{array}{c}\text { Share } \\
\text { in Total, } \%\end{array}$ & $\begin{array}{l}\text { Number } \\
\text { of obs. }\end{array}$ & $\begin{array}{c}\text { Share } \\
\text { in Total, \% }\end{array}$ \\
\hline $\begin{array}{l}\text { Application procedures for loans or lines } \\
\text { of credit are complicate }\end{array}$ & 135 & 5.0 & 203 & 4.7 & 338 & 4.9 \\
\hline Collateral requirements are too high & 142 & 5.3 & 141 & 3.3 & 283 & 4.1 \\
\hline Did not think it would be approved & 69 & 2.6 & 96 & 2.2 & 165 & 2.4 \\
\hline Don't know & 60 & 2.2 & 103 & 2.4 & 163 & 2.3 \\
\hline Interest rates are not favorable & 367 & 13.7 & 450 & 10.5 & 817 & 11.7 \\
\hline $\begin{array}{l}\text { It is necessary to make informal payments } \\
\text { to get bank loans }\end{array}$ & 24 & 0.9 & 12 & 0.3 & 36 & 0.5 \\
\hline $\begin{array}{l}\text { No need for a loan - establishment has } \\
\text { sufficient capital }\end{array}$ & 1787 & 66.8 & 3126 & 72.9 & 4913 & 70.5 \\
\hline Other & 71 & 2.7 & 130 & 3.0 & 201 & 2.9 \\
\hline Size of loan or maturity are insufficient & 21 & 0.8 & 29 & 0.7 & 50 & 0.7 \\
\hline Total & 2676 & 100 & 4290 & 100 & 6966 & 100 \\
\hline
\end{tabular}

Source: BEEPS

We find from estimation of the determinants of variable Have_loan (9) strong evidence in support of the fact that manufacturing firms are more probable borrowers on the existing loans pointing to the fundamental importance for this industry to have adequate access to finance in order to develop the businesses. The same is confirmed from the estimation of the probability that the company does not need a loan (variable No_need_loan). Namely, the firm operating in the manufacturing business is less likely to 'need no loan' as the reason for not having applied for a loan. This result is statistically significant. Moreover, testing the determinants of the probability that the reason for not having a loan is because of too high interest rates and unfavorable loan terms such as maturity, loan size, and collateral requirement, result in the same line of arguments. Manufacturing businesses are more likely to face these obstacles.
Among other results on the impact of explanatory variables in the models is evidence that small firms are less likely to use a loan and less likely to need a loan contributing to the conclusion that the financial system is set in a way that small firms face more financing obstacles. Foreign-owned firms are less likely to use a loan, probably in line with the fact that FDIs have access to capital from their owners and rely less on external financing. This result is coherent with the result on specific reasons for not having applied for a loan. Namely, foreign firms are more likely to answer that they need no loan while they are less likely to find interest rates as too high and other loan terms as not favorable. This finding corresponds to the hypothesis that foreign companies are more in a position to get better loan terms or to take cross-border loans at more favorable interest rates. The last explanation is also coherent with the reference to the theoretical model of Dell'Ariccia and Marquez (2003).

Table 9. Probit model for determinants of loan demand: marginal effects

\begin{tabular}{|c|c|c|c|c|}
\hline \multirow{2}{*}{ Dependent variable } & Have_loan & No_need_loan & $\begin{array}{l}\text { Interest_rates_ } \\
\text { not_favorable }\end{array}$ & $\begin{array}{c}\text { Not_favorable_ } \\
\text { loan_terms }\end{array}$ \\
\hline & (1) & (2) & (3) & (4) \\
\hline Manufacturing_dummy & $0.034 * *$ & $-0.062 * * *$ & $0.026 * * *$ & $0.045 * * *$ \\
\hline Large & $0.100 * * *$ & $0.035^{*}$ & -0.020 & $-0.026^{*}$ \\
\hline Small & $-0.157 * * *$ & $-0.040 * * *$ & $0.021 * *$ & $0.036^{* * *}$ \\
\hline Sales_exported & -0.000 & 0.000 & 0.000 & 0.000 \\
\hline Foreign_capital & $-0.002 * * *$ & $0.001 * * *$ & $0.001 * * *$ & $0.001 * * *$ \\
\hline State_capital & $-0.002 * * *$ & $-0.001 *$ & $-0.001 *$ & 0.000 \\
\hline
\end{tabular}


Продовження табл. 9

\begin{tabular}{|l|c|c|c|c|}
\hline \multirow{2}{*}{ Dependent variable } & Have_loan & No_need_loan & $\begin{array}{c}\text { Interest_rates_ } \\
\text { not_favorable }\end{array}$ & $\begin{array}{c}\text { Not_favorable_ } \\
\text { loan_terms }\end{array}$ \\
\cline { 2 - 5 } & $\mathbf{( 1 )}$ & $\mathbf{( 2 )}$ & -0.007 & -0.003 \\
\hline Overdue_utilities_taxes & $0.071^{* *}$ & $-0.215^{* * *}$ & -0.003 & -0.003 \\
\hline Ln_old & $0.019^{*}$ & -0.008 & 0.017 & 0.028 \\
\hline $\begin{array}{l}\text { Pressure_domestic_ } \\
\text { competitors }\end{array}$ & 0.014 & -0.016 & $-0.020^{*}$ & $-0.027^{* *}$ \\
\hline $\begin{array}{l}\text { Pressure_foreign_ } \\
\text { competitors }\end{array}$ & 0.010 & 0.004 & 0.018 & 0.021 \\
\hline Pressure_customers & 0.003 & -0.014 & -0.006 & -0.013 \\
\hline $\begin{array}{l}\text { Audited_financial_ } \\
\text { statements }\end{array}$ & $0.052^{* * *}$ & $0.043^{* * *}$ & $-0.029 * * *$ & $-0.043^{* * *}$ \\
\hline Quality_certification & 0.026 & $0.049 * * *$ & -0.01 & -0.014 \\
\hline Employees_growth & $0.101^{* * *}$ & $0.036^{* * *}$ & 0.011 & 0.010 \\
\hline Crisis_dummy & 0.014 & -0.025 & $0.001 * *$ & $0.003 * * *$ \\
\hline Credit_to_GDP & $0.001 * * *$ & $-0.004 * * *$ & 5,583 & 5,583 \\
\hline Observations & 5,948 & 5,494 & 0.0000 & 0.0000 \\
\hline Prob>chi2 & 0.0000 & 0.0000 & 0.09 & 0.08 \\
\hline pseudo R2 & 0.10 & 0.07 & & \\
\hline
\end{tabular}

$* \mathrm{p}<0.1 ; * * \mathrm{p}<0.05 ; * * * \mathrm{p}<0.01$

Table 10. Distribution of observations on reasons for not applying for a loan across the status of existing external debt

\begin{tabular}{|c|c|c|c|c|c|c|}
\hline \multirow{2}{*}{$\begin{array}{l}\text { «What was the main reason why this } \\
\text { establishment did not apply for any line } \\
\text { of credit or loan in fiscal year preceding } \\
\text { the year of survey?» }\end{array}$} & \multicolumn{2}{|c|}{ Have a loan } & \multicolumn{2}{|c|}{ Do not have a loan } & \multicolumn{2}{|c|}{ Total } \\
\hline & $\begin{array}{l}\text { Number } \\
\text { of obs. }\end{array}$ & $\begin{array}{l}\text { Share in } \\
\text { Total, \% }\end{array}$ & $\begin{array}{l}\text { Number } \\
\text { of obs. }\end{array}$ & $\begin{array}{c}\text { Share } \\
\text { in Total, \% }\end{array}$ & $\begin{array}{l}\text { Number } \\
\text { of obs. }\end{array}$ & $\begin{array}{c}\text { Share } \\
\text { in Total, \% }\end{array}$ \\
\hline $\begin{array}{l}\text { Application procedures for loans or lines } \\
\text { of credit are complicate }\end{array}$ & 56 & 3.8 & 167 & 5.3 & 223 & 4.8 \\
\hline Collateral requirements are too high & 47 & 3.2 & 152 & 4.8 & 199 & 4.3 \\
\hline Did not think it would be approved & 53 & 3.6 & 63 & 2.0 & 116 & 2.5 \\
\hline Don't know & 69 & 4.7 & 53 & 1.7 & 122 & 2.6 \\
\hline Interest rates are not favorable & 133 & 9.1 & 470 & 14.9 & 603 & 13.1 \\
\hline $\begin{array}{l}\text { It is necessary to make informal } \\
\text { payments to get bank loans }\end{array}$ & 18 & 1.2 & 17 & 0.5 & 35 & 0.8 \\
\hline $\begin{array}{l}\text { No need for a loan - establishment has } \\
\text { sufficient capital }\end{array}$ & 1,001 & 68.4 & 2,117 & 67.3 & 3,118 & 67.7 \\
\hline Other & 71 & 4.8 & 71 & 2.3 & 142 & 3.1 \\
\hline Size of loan or maturity are insufficient & 16 & 1.1 & 34 & 1.1 & 50 & 1.1 \\
\hline Total & 1,464 & 100 & 3,144 & 100 & 4,608 & 100 \\
\hline
\end{tabular}

Source: BEEPS

\section{Discussion of results, conclusion, and policy implications}

The empirical estimation presented in the previous section provides strong evidence on the representative sample of firms in 18 European transition countries that manufacturing firms face relatively more problems in accessing finance for their businesses than other sectors. The result is robust after controlling for the firm's size, owner (state, private of foreign), transparency (quality of accounting and possession of quality certificates), pressures from competition on the local and international markets, age, ownership, and country-level characteristic of 
the financial system. The same finding is confirmed on the sub-sample of companies that not use a loan. By running separate models for determinants of the probability that a firm uses a bank loan it was revealed that manufacturing businesses rely more on bank loans. Further on, by testing the determinants of the likelihood that a firm uses a bank loan, we obtained the statistically significant result that manufacturing businesses rely relatively more on external financing. By testing the reasons for the absence of demand for loans on the subsample of firms that did not ask for a loan or a credit line in the year preceding the survey, the evidence points to the fact that manufacturing firms are less likely to answer that they do not need a loan, while they are more likely to face obstacles in the price of borrowing and in other terms.

How can the finding that manufacturing businesses face more financial constraint in transition economies be interpreted? The supply of loans is determined by the banking sector situation and the last was critically influenced by inflows of foreign capital which was relatively cheap during the observed period (except in late 2008 and 2009, and we control for that) and of the relatively short-term. On the other side, local deposits by citizens are also of relatively short-term. One of possible constraints may be found in the fact that the supply of loans is consequently of relatively short maturity. The last may not match with the financial needs of manufacturing businesses (they may need long-term investment loans). Another - price explanation (as evidenced also from empirical estimation) may result in the following mechanism. The interpretation is based on the information asymmetry theory. Since the majority of loans are intermediated by foreign banks, as uninformed lenders, these banks account in their cost of capital a certain market risk. The expected return on investment by an uninformed foreign investor in emerging markets is closely related to the sovereign rating of the country. Since there is no perfect solution to price the risk of an investment in the economies with underdeveloped financial markets and scarce information, most of the recommended models for calculating the expected return (cost of capital) consist of including the risk premium for the country risk corresponding to the sovereign rating. Thus, the overall risk of the economy is assigned to all potential investments to businesses in that economy. Moreover, additional premiums for specific sectors of the economy from developed markets are usually added to the risk free interest rate from developed markets (Bancel, 1999; Vernimmen, 2006).

This risk, preliminarily priced as a high one, faces some lenders from lower risk businesses (lower return rates, and longer periods of return of investment, such as most of the manufacturing industry, but probably less risk in terms of longterm volatility) with discouraging costs of borrowing and leaves them out of the lending market. This expected return translated into lending interest rates could induce the well known "lemon problem" (Akerlof, 1970) on the lending market where less risky (less profitable) borrowers get out from the market when they are offered an interest rate on external financing corresponding to the average risk. This interest rate is probably unbearable for enterprises in sectors of activity where periods of return of investment are longer and returns are lower, but more stable and less risky comparing to the overall country/market risk. It can be the case of the manufacturing industry in transition countries, which accounts for the major part of exports at the same time.

In other words, the overall price of financing may have been too high for the majority of manufacturing businesses. Namely, the manufacturing businesses are not equally profitable (at least not in the short run) as the real estate, construction, or trade businesses (in the period of boom in demand and consumption) but need a longer perspective for the development of investment and market for products. Thus, we might have witnessed a 'lemon problem' phenomenon during the financial expansion period. At the same time the supply of loans was abundant but given its relatively high price levels, the 'good risks' were out of the market demand as the interest rate level was unbearable for their businesses. Those businesses that could estimate by themselves the burden of loan financing to their cash flow were 'good risks'. On the other hand, more profitable businesses at the time (but more volatile once the crisis hit) or those unable to estimate their future cash flow once they borrow from a bank, were on the demand for loans side.

The relative interest rate level was high as a result of information asymmetry. Namely, by the rules of the financial markets, once a country is not in good macroeconomic shape it receives a lower rating, which implies a spread on the risk free rate. This spread is lowest for sovereign debt, and builds on top of that for other businesses and citizens in that country. Besides a higher interest rate induced 
from the higher country spread, the market power in some market segments (of less transparent borrowers), may also result in a certain mark-up, i.e. in higher rates as a result of the market power of banks versus certain client categories. This last finding is probably in line with the main hypothesis in the explanation behind the financial constraint of manufacturing businesses.

Translating the last phenomena on the macroeconomic scale, this distortion in the lending market may push uneven growth in sectors with higher returns (able to pay high interest rates). These are more likely services sectors, which, unlike manufacturing sectors, do not participate in the overall exports of the country. In that way, besides pushing growth, this mechanism also contributes to unsustainable levels of the current account deficits in these countries, which, together with high levels of accumulated external debt, create the high external financing needs of these countries, all three variables being strong determinants of the country's risk perception by international rating agencies.

One interpretation of these findings is that finance does matter for growth as an uneven development of tradable and non-tradable sectors in transition economies in the period of large financial inflows reflected in current account deficits. We may suppose that at least part of the origin of these deficits was in uneven access to finance. Further investigation of reasons within the access to finance obstacle is necessary. It may have something to do with the specific features of financial intermediation in transition economies during the credit expansion.

We have brought here some insights that could generate specific policies aimed at helping the problem of information asymmetry in pricing the lower risks in transition economies. If the proposed mechanism is in place in transition economies, it opens a new stream for future research. Moreover, it offers a valuable path for innovative policies solutions in transition countries, which could help mitigate the accumulated macroeconomic imbalances and provide the environment for future economic development based on financial integration at the same time.

One of the possible solutions that naturally emerge would be the reconsidering of the role of the state in financial intermediation in these countries. We are all aware of the benefits of denationalization of the banking sector in transition economies and the withdrawal of the state from direct impact on lending through the monetary policy, as was the case before the transition was launched. Nevertheless, the idea of the state action in helping the access to finance of the private sector in developing countries is not novel or unconsidered. Yet, the recent empirical analysis and discussion papers are rather in favor of some kind of soft state intervention ('visible hand') in the form of rules and regulation that promote, indirectly, the access to finance opaque in terms of information, but still valuable projects (De la Torre, 2007).

The policies should aim to mitigate information asymmetry, but also to correct for evident market failures. The inflowing capital maturity is to the large extent determined by the risk perception, same as the level of calculated risk spread in the price of financing. The country risk is in large part determined by the current account deficit level (higher deficit result in lower rating and higher spread). Another important element of rating is a fiscal deficit and political stability. The last create a vicious cycle of uneven access to finance, expensive finance, foreign investors' perception of high country risk and consequent expensive foreign borrowing and maturity structure of inflowing capital in favor of the short-term over the long-term. The exit from the vicious cycle is in political and institutional stabilization, but also in rebalancing of the economy. Special attention should be directed into tradable sector financing. Further investigation is needed to verify the last interpretation of results and to design policies that target the specific market failures.

\section{References}

1. Bancel, F., \& Perrotin, T., (1999). Le coût du capital dans les pays émergents. Revue d'analyse financière, 119, 76-88.

2. Beck, T., \& Demirgüç-Kunt, A. (2006). Small and medium-size enterprises: Access to finance as a growth constraint. Journal of Banking and Finance, 30 (11), 2931-2943.

3. De la Torre, Gozzi, A. J. C., \& Schmukler, S. (2007). Innovative Experiences in Access to Finance: Market Friendly Roles for the Visible Hand? Policy Research Working Paper, The World Bank, 4326 .
4. Dell'Ariccia, G., \& Marquez, R. (2004). Information and Bank Credit Allocation. Journal of Financial Economics, 72 (1), 185-214.

5. Dimitrijević (Atanasijević), J., \& Najman, B. (2008). Inside the credit boom: competition, segmentation and information: the evidence from the Serbian credit market, Comparative Economics Studies, 50 (3), 217-252.

6. EBRD. (2009). Transition report 2009. London: EBRD.

7. EBRD. (2010). BEEPS 2008-2009: A Report on Methodology and Observations, London: EBRD. 
8. Fanelli, J. M., \& Keifman, S. (2002). Finance and Changing Patterns in Developing Countries. Journal of Finance and Accounting, 15 (4), 143-171.

9. Kornai, J. (1979). Resource-Constrained versus Demand-Constrained Systems. Econometrica, 47 (4), 801-19.
10. Sen, A. (1999). Developments as Freedom. Oxford: Oxford University Press.

11. Vernimmen, P. (2006). Finance d'Entreprises. Paris: DallozSirey.

Атанасієвич Я., Нажман Б.

\section{ФІНАНСОВА ІНТЕГРАЦІЯ ТА МАКРОЕКОНОМІЧНА СТАБІЛЬНІСТЬ: СЕКТОРАЛЬНИЙ ПІДХІД ДО АНАЛІЗУ ДОСТУПУ ДО ФІНАНСУВАННЯ ТА МОДЕЛЬ ПЕРЕДКРИЗОВОГО ЗРОСТАННЯ}

У статті на основі результатів опитування підприємств із бази даних СБРР за 2002-2008 роки проаналізовано основні перешкоди для отримання фінансування у 18 європейських країнах із перехідною економікою. Для усіх країн характерним є те, що у передкризовий період в основу свого розвитку вони закладали фінансову інтеграцію (ЕБРР, 2009). Глибинний аналіз перешкод для доступу підприємств до фінансування забезпечує розуміння процесу фінансового розвитку та його виливу на економічне зростання у реальному секторі. Основними результатами емпіричного оиінювання методом пробіт-моделювання є висновок, що більші перешкоди для доступу до фінансових ресурсів існують для промислового сектора порівняно з іншими галузями. Недоступність фінансування є вагомою перепоною розвитку підприємства, до того ж промислові компаніі мають більші потреби у кредитних коштах. Причинами невикористання фірмами банківських позик є високі відсотки та інші нецінові невигідні умови такого фінансування. Цей результат ліг в основу загальної гіпотези щодо ролі фінансового сектора у моделі економічного зростання в країнах із перехідною економікою в період до кризи. Сутність ї̈ полягає в тому, що два десятиліття нерівномірного доступу до фінансування для виробничих підприємств (зокрема тих, щяо виробляють товари для торгівлі) привели до структурних дисбалансів у реальному секторі, які проявилися у торговому дефіциті, тобто недорозвиненому торговельному та надмірному неторговельному секторах.

Ключові слова: доступ до фінансів, перехідний період, фірми. 